\title{
Evaluation of Antioxidant Potential of Clarias Batrachus Oil in Alloxan Induced Diabetic Mice (Mus Musculus)
}

\section{Shantal G Kamat and Ramaballav Roy*}

Department of Zoology, Goa University, Taleigao Plateau 403206, Goa, India

\begin{abstract}
Introduction: Diabetes mellitus is a chronic disorder in human and responsible for different complications and also causes mortality and morbidity. Long chain fatty acids influence inflammation through a variety of mechanisms; many of these are mediated by, or at least associated with, changes in fatty acid composition of cell membranes. Hence the present study was performed to investigate the effect of fish oil extracted from Clarias batrachus which is a good source of PUFA n-3 among freshwater species on alloxan-induced diabetic mice.

Material and method: Alloxan was administered at repetitive doses $\left(100 \mathrm{mg} / \mathrm{kg} \mathrm{b} . w \mathrm{t}\right.$ after every $5^{\text {th }}$ day for a period of one month to induce diabetes in mice. Along with alloxan injection, $10 \%$ Clarias fish oil was supplemented to diabetic mice for a period of one month. Analysis of basic antioxidant and lipid peroxidation parameters in serum, liver, kidney, heart and pancreatic tissues was carried out.

Result: The levels of antioxidant and lipid peroxidation markers were significantly $(P<0.05)$ altered in all the tissues of alloxan-induced diabetic mice. The supplementation of fish oil to diabetic mice showed significant recovery in activity of enzymes SOD, Catalase and in concentration of Vitamin C which is decreased in diabetic control mice.

Conclusion: The result of this study indicated fish oil supplementation in diabetic mice helped to reduce the elevated glucose and glycosylated haemoglobin level along with an increase in insulin concentration and helped to recover the altered antioxidant and enzyme activity, which specifies that long term treatment of diabetes with fish oil may help to reduce the diabetes induced tissue damages.
\end{abstract}

Keywords: PUFA; Clarias batrachus; Fish oil; Diabetes; Oxidative stress; Tissue damage

Abbreviations: PUFA: Poly Unsaturated Fatty Acid; ALT: Alanine Transaminase; AST: Aspartate Transaminase; ALP: Alkaline Phosphates; LDH: Lactate Dehydrogenase; ACP: Acid Phosphatase; GGT: Gamma Glutmmyl Transpeptidase; CAT: Catalase; TBARS: Thiobutaric Acid Reactive Substance; GSH: Reduced Glutathione; SOD: Superoxide Dismutase; ROS: Reactive Oxygen Species

\section{Introduction}

Oxidative stress, which has been implicated in a wide variety of degenerative processes and diseases, plays an important role in the aetiology of diabetes mellitus (DM), due to weakling of antioxidant defence or excess production of free radicals that can overwhelm the scavenging capacity of cellular antioxidant systems. DM is a pathologic condition, is possibly the world's fastest growing metabolic disorder, resulting in severe metabolic changes in many tissues and one of the major causes of death [1]. The hyperglycemia of diabetes is believed to be responsible for the recognized vascular complications. Several mechanisms, like changes in lipid metabolism [2], imbalance between production of reactive oxygen species (ROS) and antioxidant defence mechanism [3], changes in the inflammatory pathway [4] which play an important role in increased oxidative stress in diabetes. Diabetes is associated with the generation of reactive oxygen species which cause oxidative damage which is associated with complications like hypercholesterolemia, hypertriglyceridemia, atherosclerosis, coronary heart disease, renal malfunctioning and hypertension [5]. The increased oxidative stress and inflammation are widely accepted causes in the development of diabetes and related complication [6].

Lipids are one of the main macronutrient which serves both structural and metabolic functions. A dietary lipid plays an important role in physiological processes and thus helps to maintain health. Several studies have shown that fatty acids effects on oxidative stress and inflammation through a variety of mechanisms [7-9], which are mediated by or associated with changes in fatty acid composition of cell membranes. These changes help to modify the fluidity of membrane, cell signaling leading to altered gene expression and lipid metabolism [10]. The n-3 PUFA supplementation helps to control the oxidative stress and inflammation progression, suggest that the level of exposure to these fatty acids might be important in determining the development and severity of oxidative stress and inflammation. Researchers have shown that several diseases are associated with lower levels of omega-3 and omega-6 PUFAs. Long chain PUFA deficiency has also been observed in diabetes [11]. Polyunsaturated Fatty Acids (PUFA), particularly eicosapentaenoic acid (EPA; 20:5n-3) and docosahexaenoic acid (DHA; 22:6n-3) present in marine sources, have been found to have healing effects against several of oxidative stress related complications $[5,12]$. Hence, the objective of the present study is to test the hypothesis that dietary fish oil supplementation from fresh water fish Clarias batrachus which is a good source of PUFA may help to prevent the oxidative stress induced tissue damages in diabetes.

${ }^{*}$ Corresponding author: Dr. Ramaballav Roy, Department of Zoology, Goa University, Taleigao Plateau 403206, Goa, India, Tel: +91-9421241643; E-mail: rroy@unigoa.ac.in

Received April 10, 2015; Accepted May 11, 2015; Published May 15, 2015

Citation: Kamat SG, Roy R (2015) Evaluation of Antioxidant Potential of Clarias Batrachus Oil in Alloxan Induced Diabetic Mice (Mus Musculus). J Diabetes Metab 6: 552. doi:10.4172/2155-6156.1000552

Copyright: @ 2015 Kamat SG, et al. This is an open-access article distributed under the terms of the Creative Commons Attribution License, which permits unrestricted use, distribution, and reproduction in any medium, provided the original author and source are credited. 


\section{Materials and Methods}

\section{Extraction of fish oil}

$250 \mathrm{~g}$ of muscle tissue of fish Clarias batrachus was sonicated with hexane at temperature $30^{\circ} \mathrm{C}$ for one hour with time interval of 5 minutes after every 15 minutes to avoid the heat generation due to sonication. The filtrate was collected under vacuum and the residue was re-sonicated once again with hexane and the filtrate was collected. Both the filtrates are pooled together and concentrated using Rotary vacuum evaporator to remove hexane completely (From the $250 \mathrm{~g}$ of muscle tissue $25 \mathrm{ml}$ yield of oil was obtained). $0.1 \mu$ mole of BHT (butylated hydroxyl toluene) was added to the oil in order to prevent oxidation. The oil was stored in an amber colour bottle and refrigerated. A fatty acid profile (Table 1) analysis of the fish oil was carried out using GCMS.

\section{Study design}

Prior permission of Animal Ethics Committee, Goa University was taken to use the Swiss albino mice for the study. All mice received humane care and maintained according to the guidelines of CPCSEA (Committee for the Purpose of Control and Supervision on Experiments on Animals, Govt. of India). Two month old Swiss albino mice Mus musculus were selected for the study. After acclimatization for 2 weeks to laboratory condition the mice were divided into three groups, with 6 numbers in each and labelled as PC, PD, CD

Group PC: Standard Control. Normal mice supplemented with normal pellet feed followed by water ad libitum, injected with normal saline, no extra diet components were given.

Group PD: Diabetic Control. Mice induced diabetes by intraperitoneal injection of alloxan ( $100 \mathrm{mg} / \mathrm{kg}$ b.wt. in $20 \mu \mathrm{l}$ of saline) fed with normal pellet feed followed by water ad libitum with no extra diet components.

Group CD: Clarias batrachus Group. Diabetic mice supplemented pellet feed freshly blended with laboratory extracted $10 \%$ Clarias batrachus fish oil followed by water ad libitum.

The hyperglycemia condition in diabetes maintained throughout the study in Group PD and Group CD by repetitive doses of intraperitoneal injection of alloxan $[13,14](100 \mathrm{mg} / \mathrm{kg}$ b.wt. in saline $)$ after every $5^{\text {th }}$ day for a period of one month, where Group CD received supplementation of fish oil along with an injection. There was no mortality observed during the experimental period. After 30 days of feeding experiment, animals were anesthetized and sacrificed. The blood was collected from Mus musculus by cardiac puncture with moderate suction. The needle was removed before transferring blood to the appendorf tubes to avoid any haemolysis for the collection of serum [15]. For serum collection, blood was allowed to clot completely at room temperature for a period of half an hour, appendorf tubes were centrifuged at $4^{\circ} \mathrm{C}$ for $800 \mathrm{x} g$ for 10 minutes and serum was separated. It was immediately stored in liquid nitrogen $\left(-196^{\circ} \mathrm{C}\right)$ for further biochemical analysis, also the liver, kidney, heart and pancreas tissues were collected for further analysis.

\section{Biochemical analysis}

The insulin concentration was determined in serum with chemiluminescence ELISA kit (ALPCO, Keewaydin Drive, Salem) using 96-well micro plate coated with monoclonal antibody specific for insulin. The standards, controls, and samples were added to the micro plate wells with the conjugate. The micro plate is then incubated at room temperature on a micro plate shaker at $700-900 \mathrm{rpm}$. After the incubation is completed the wells were washed with Wash Buffer and blotted dry. Chemiluminescent Substrate was added, and the micro plate was read by a luminescence plate reader after 1 minute. The intensity of the light generated is directly proportional to the amount of insulin in the sample. To measure the concentration of free sugar in serum, to the $1.0 \mathrm{ml}$ de-proteinized sample, $1.0 \mathrm{ml}$ alkaline copper reagent was added and incubated in the boiling water bath for 20 minutes. After cooling to room temperature $1 \mathrm{ml}$ of arseno-molybdate colour reagent was added. The mixture was diluted with $7 \mathrm{ml}$ distilled water. The intensity of the colour was read at $540 \mathrm{~nm}$ against a suitable blank [16]. Glycosylated haemoglobin was measured in serum by adding $1 \mathrm{ml}$ of oxalic acid reagent is to the dilute hemolysate and kept in boiling water bath for an hour. Tubes were cooled to room temperature and $1 \mathrm{ml}$ of TCA reagent was added mixed thoroughly. Centrifuged at $3000 \mathrm{rpm}$, to the supernatant $0.5 \mathrm{ml}$ of thiobarbituric acid was added and kept at $37^{\circ} \mathrm{C}$ for 40 minutes. The reading was taken against a blank ( $2 \mathrm{ml}$ water and $0.5 \mathrm{ml}$ thiobarbituric acid) at $443 \mathrm{~nm}$ [17].

\section{Lipid peroxidation and antioxidant parameters analysis}

To check the shift in lipid peroxidation and antioxidant status, concentration of Vitamin C, using dinitrophenyl hydrazine, Vitamin $\mathrm{E}$, using ferric chloride reagent, thiobarbituric acid reactive species (TBARS), using TBA-TCA-HCL reagent, reduced glutathione (GSH), using 5,5-dithiobis, 2-nitrobenzoic acid, activity of superoxide dismutase (SOD), by using SOD substrate reagent, catalase by using dichromate acetic acid reagent and activity of gamma glutammyl trans peptidase (GGT), by using glacial acetic acid reagent, were measured according to standard protocols $[18,19]$ in serum, liver, kidney, heart and pancreas.

\section{Enzyme activity analysis}

To check the tissue damage, activities of functional enzymes alanine transaminase (ALT), aspartate transaminase (AST), alkaline phosphatase (ALP), lactate dehydrogenase (LDH), acid phosphatase (ACP), was measured as described by Godkar [18] in serum, liver, heart, kidney and pancreas tissues.

Statistical analyses: One-way ANOVA was performed using the IBM SPSS Statistic (Statistical Package for the Social Sciences), Version 21 for comparison between the control, diabetes and diabetes plus fish oil administered groups. The difference between the two groups was analysed by using student $t$ test. The results were represented as mean \pm standard error.

\begin{tabular}{|c|c|}
\hline Type of Fatty acid & \% Composition \\
\hline C14:0 (Myristic) & $11.54 \pm 0.23$ \\
C16:0 (Palmitic) & $15.76 \pm 0.39$ \\
C16:1 (Palmitoleic) & $8.03 \pm 0.70$ \\
C16:3 (Hexadecatrienoic) & $2.42 \pm 0.10$ \\
C18:0 (Stearic) & $7.27 \pm 0.21$ \\
C18:1 (Oleic) & $10.17 \pm 0.69$ \\
C18:2 (n-6, Lenoleic) & $6.94 \pm 0.33$ \\
C20:1 (Eicosenoic) & $1.49 \pm 0.18$ \\
C20:3 (n-6, Eicosatrienoic) & $2.67 \pm 0.26$ \\
C20:4 (n-6, Eicosatetraenoic) & $5.77 \pm 0.066$ \\
C20:5 (n-3, Eicosapentanoic) & $9.64 \pm 0.57$ \\
C22:5 (n-3, Docosapentanoic) & $5.83 \pm 0.35$ \\
C22:6 (n-3, Docosahexanoic) & $12.47 \pm 0.72$ \\
\hline Total saturated & 56.68 \\
Total Unsaturated & 43.32 \\
Total n3 & 27.94 \\
Total n6 & 15.38 \\
\hline
\end{tabular}

Table 1: Fatty acid composition (relative percentage) of oil extracted from Clarias batrachus (Mean values of 3 sets of analysis). 


\section{Results}

\section{Effect on free sugar, glycosylated haemoglobin and insulin} level

Table 2 shows that in the control group treatment with normal saline did not affect the normal free sugar, glycosylated haemoglobin and insulin concentration of serum. Alloxan treatment resulted in significant $(P<0.001)$ 5-6 fold increase in free sugar, glycosylated haemoglobin level with a $50 \%$ decrease in insulin level in serum in diabetic group when compared with control. The supplementation of fish oil to the diabetic group helped to reduce significantly $(P<0.05$ 0.01 ) these elevated levels by $48-60 \%$ and increase insulin level by $38 \%$ when compared with the diabetic control group.

\section{Effect on lipid peroxidation and antioxidant parameters}

Due to prolonged diabetes the level of Vitamin C, Vitamin E and GSH was significantly $(P<0.001)$ decreased by $24-89 \%$, while the level of TBARS (Table 3) was increased in liver, kidney, heart, pancreas and serum of the alloxan induced diabetic control mice when compared with the control group of mice which maintained normal optimal value. The similar pattern of changes was also observed in activity of antioxidant enzymes (Table 4) SOD and catalase, which decreased significantly in all the tissues by $20-40 \%$ with a significant increase $(P<0.001)$ in the activity of GGT from $30-100 \%$ in the diabetic group of mice when compared to control. The Clarias oil supplementation helped to reduce significantly this elevated level of TBARS concentration along with augmentation in decreased concentration of antioxidant Vitamin $\mathrm{C}$ by 40\%-1.1fold and the activities of SOD and catalase by $16-40 \%$ in all the tissues when compared to diabetic mice. There are no significant changes observed with respect to Vitamin E and GSH concentration and GGT activity in all the tissues of diabetic mice supplemented with Clarias oil when compared with diabetic control.

\section{Effect on functional enzyme activities}

Induction of diabetes resulted in the changes of activities of functional enzymes in tissues serum, liver, kidney, heart and pancreas. The prolonged diabetes significantly elevated the activities of alanine transaminase, aspartate transaminase, alkaline phosphatase, lactate dehydrogenase and acid phosphatase (Table 5 ) by $45 \%$ to 2.5 folds in liver, kidney, heart, pancreas and serum. Following supplementation with Clarias fish oil these elevated levels of enzymatic activity decreased significantly $(P<0.001)$.

\section{Discussion}

Diabetes mellitus which is caused by lack in secretion of insulin or the loss of its function on target tissue, primarily characterized by an inefficient utilization of circulating glucose, leading to consistent hyperglycaemic condition. It has been considered as one of the major health concerns all around the world today. Alloxan-induced diabetes, establishing a redox cycle for generation of ROS and superoxide radicals has been commonly employed as an experimental model of insulin dependent diabetes mellitus [20]. Disturbances in the normal redox state of cells due to oxidative stress can cause toxic effects through the production of peroxides and free radicals that damage all components of the cell, including proteins, lipids, and DNA causing metabolic abnormalities associated with diabetes [21]. Researchers over past several years showed importance of poly unsaturated fatty acids (PUFA) mainly omega- 3 and omega- 6 in advancement of health and in disease prevention. These two PUFAs are labelled as essential

\begin{tabular}{|c|c|}
\hline Groups & Insulin $(\mathbf{n g} / \mathbf{m})$ \\
\hline PC & $0.820 \pm 0.011$ \\
\hline PD & $0.418 \pm 0.010$ \\
CD & $0.574 \pm 0.014$ \\
\hline
\end{tabular}

Free sugar $(\mathbf{m g} / \mathbf{d l})$
$76.38 \pm 11.5$
$566.1 \pm 13.8^{\star}$
$290 \pm 8.5^{\star} \dagger$

Glycosylated haemoglobin $(\mathrm{mmol} / \mathrm{mol})$

$24.35 \pm 0.45$

$155.3 \pm 1.62^{*}$

$69.2 \pm 2.66^{*} \dagger$

The significant difference between groups for each tissue based on student $t$ test represented by * compared to PC, $\dagger$ compared to PD. PC: Standard control, PD: Diabetic control, CD: Clarias oil group

Table 2: Effect of dietary supplementation of fish oils for 30 days on serum insulin, free sugar and glycosylated haemoglobin level in alloxan induced diabetic mice (Mus musculus). Data represented as mean of six values and their standard errors.

\begin{tabular}{|c|c|c|c|c|c|}
\hline Tissues & Groups & $\begin{array}{l}\text { Vitamin C } \\
(\mu \text { mole })\end{array}$ & $\begin{array}{l}\text { Vitamin E } \\
(\mu \mathrm{mole})\end{array}$ & $\begin{array}{l}\text { TBARS } \\
(\mu \text { mole MDA })\end{array}$ & $\begin{array}{l}\text { GSH } \\
\text { ( } \mu \text { mole) }\end{array}$ \\
\hline \multirow{3}{*}{$\begin{array}{l}\text { Liver } \\
\text { (per } 100 \mathrm{mg} \text { of tissue) }\end{array}$} & PC & $10.2 \pm 1.45$ & $62.2 \pm 0.89$ & $0.268 \pm 0.018$ & $0.473 \pm 0.076$ \\
\hline & PD & $4.02 \pm 0.28^{*}$ & $47.3 \pm 1.2^{*}$ & $0.581 \pm 0.048^{*}$ & $0.217 \pm 0.015^{*}$ \\
\hline & $C D$ & $8.43 \pm 2.8 \dagger$ & $50.4 \pm 1.02^{*}$ & $0.407 \pm 0.020^{*} \dagger$ & $0.250 \pm 0.034^{*}$ \\
\hline \multirow{3}{*}{$\begin{array}{l}\text { Kidney } \\
\text { (per } 100 \mathrm{mg} \text { of tissue) }\end{array}$} & PC & $8.38 \pm 1.14$ & $59.6 \pm 0.99$ & $0.222 \pm 0.011$ & $0.469 \pm 0.052$ \\
\hline & PD & $2.84 \pm 0.14^{*}$ & $44.4 \pm 0.75^{*}$ & $0.526 \pm 0.015^{*}$ & $0.207 \pm 0.032^{*}$ \\
\hline & CD & $7.96 \pm 1.15 \dagger$ & $46.4 \pm 0.67^{*}$ & $0.362 \pm 0.018^{*} \dagger$ & $0.232 \pm 0.013^{*}$ \\
\hline \multirow{3}{*}{$\begin{array}{l}\text { Heart } \\
\text { (per } 100 \mathrm{mg} \text { of tissue) }\end{array}$} & PC & $7.77 \pm 0.84$ & $55.7 \pm 1.5$ & $0.247 \pm 0.018$ & $0.444 \pm 0.012$ \\
\hline & PD & $3.54 \pm 0.28^{*}$ & $42.3 \pm 1.9^{*}$ & $0.581 \pm 0.039^{*}$ & $0.215 \pm 0.011^{*}$ \\
\hline & $C D$ & $6.6 \pm 0.39 \dagger$ & $46.5 \pm 1.4^{*}$ & $0.347 \pm 0.014^{*} \dagger$ & $0.247 \pm 0.013^{*}$ \\
\hline \multirow{3}{*}{$\begin{array}{l}\text { Pancreas } \\
\text { (per } 100 \text { mg of tissue) }\end{array}$} & PC & $7.41 \pm 0.51$ & $50.07 \pm 0.83$ & $0.237 \pm 0.012$ & $0.584 \pm 0.036$ \\
\hline & PD & $3.07 \pm 0.34^{*}$ & $38.96 \pm 0.88^{*}$ & $0.450 \pm 0.013^{*}$ & $0.202 \pm 0.013^{*}$ \\
\hline & $C D$ & $4.85 \pm 0.38^{*} \dagger$ & $40.76 \pm 0.88^{*}$ & $0.251 \pm 0.012^{*} \dagger$ & $0.229 \pm 0.010^{*}$ \\
\hline \multirow{3}{*}{$\begin{array}{l}\text { Serum } \\
\text { (per ml of serum) }\end{array}$} & PC & $8.21 \pm 0.12$ & $63.0 \pm 0.12$ & $0.262 \pm 0.0036$ & $22.46 \pm 0.80$ \\
\hline & PD & $3.76 \pm 0.11^{*}$ & $33.3 \pm 0.10^{*}$ & $1.75 \pm 0.0052^{*}$ & $13.1 \pm 1.1^{*}$ \\
\hline & CD & $5.10 \pm 0.68^{*} \dagger$ & $47.1 \pm 0.10^{*} \dagger$ & $0.584 \pm 0.005^{*} \dagger$ & $19.5 \pm 1.3^{*} \dagger$ \\
\hline
\end{tabular}

The significant difference between groups for each tissue based on student t test represented by * compared to PC, $\dagger$ compared to PD.PC: Standard control, PD: Diabetic control, CD: Clarias oil group

Table 3: Effect of dietary supplementation of fish oils for 30 days on tissue antioxidant and lipid peroxidation parameters in alloxan induced diabetic mice (Mus musculus) Data represented as mean of six values and their standard errors. 
Citation: Kamat SG, Roy R (2015) Evaluation of Antioxidant Potential of Clarias Batrachus Oil in Alloxan Induced Diabetic Mice (Mus Musculus). J Diabetes Metab 6: 552. doi:10.4172/2155-6156.1000552

Page 4 of 6

\begin{tabular}{|c|c|c|c|c|}
\hline Tissues & Groups & $\begin{array}{c}\text { SOD } \\
\text { (U/mg protein) }\end{array}$ & $\begin{array}{c}\text { CAT } \\
\left(\mu \mathrm{moleH}_{2} \mathrm{O}_{2} / \mathrm{min} / \mathrm{mg} \text { protein }\right)\end{array}$ & $\begin{array}{c}\text { GGT } \\
\text { (U/ mg protein) }\end{array}$ \\
\hline \multirow{3}{*}{ Liver } & PC & $14.3 \pm 0.52$ & $165.9 \pm 0.71$ & $10.84 \pm 0.30$ \\
\hline & PD & $9.53 \pm 0.34^{*}$ & $133.6 \pm 0.73^{*}$ & $21.1 \pm 0.60^{*}$ \\
\hline & $C D$ & $11.1 \pm 0.40^{*} \dagger$ & $181.6 \pm 0.64^{*} \dagger$ & $19.8 \pm 0.45^{\star} \dagger$ \\
\hline \multirow{3}{*}{ Kidney } & PC & $11.98 \pm 0.61$ & $200.1 \pm 1.3$ & $10.12 \pm 0.36$ \\
\hline & PD & $6.78 \pm 0.59^{*}$ & $139.9 \pm 1.07^{*}$ & $16.1 \pm 0.49^{*}$ \\
\hline & $C D$ & $8.66 \pm 0.36^{*} \dagger$ & $167.7 \pm 0.91^{*} \dagger$ & $14.7 \pm 0.36^{*}$ \\
\hline \multirow{3}{*}{ Heart } & PC & $13.34 \pm 0.59$ & $151.8 \pm 1.03$ & $11.94 \pm 0.36$ \\
\hline & PD & $7.45 \pm 0.64^{*}$ & $115.4 \pm 1.35^{*}$ & $15.03 \pm 0.28^{*}$ \\
\hline & $C D$ & $9.59 \pm 0.27^{*} \dagger$ & $162.6 \pm 1.14^{*} \dagger$ & $14.1 \pm 0.34^{*}$ \\
\hline \multirow{3}{*}{ Pancreas } & PC & $12.17 \pm 0.33$ & $147.5 \pm 1.32$ & $10.2 \pm 0.36$ \\
\hline & PD & $7.21 \pm 0.31^{*}$ & $138.9 \pm 1.31^{*}$ & $14.9 \pm 0.32^{*}$ \\
\hline & $C D$ & $8.49 \pm 0.28^{*} \dagger$ & $156.4 \pm 1.36^{\star} \dagger$ & $14.1 \pm 0.36^{*}$ \\
\hline \multirow{3}{*}{ Serum } & PC & $12.03 \pm 0.33$ & $168.7 \pm 1.15$ & $12.7 \pm 0.71$ \\
\hline & PD & $8.39 \pm 0.26^{*}$ & $135.9 \pm 1.42^{*}$ & $16.1 \pm 0.88^{*}$ \\
\hline & $C D$ & $8.46 \pm 0.27^{*}$ & $188.2 \pm 1.36^{*} \dagger$ & $14.8 \pm 0.79^{*}$ \\
\hline
\end{tabular}

The significant difference between groups for each tissue based on student t test represented by * compared to PC, $†$ compared to PD.PC: Standard control, PD: Diabetic control, CD: Clarias oil group

Table 4: Effect of dietary supplementation of fish oils for 30 days on antioxidant and lipid peroxidation enzymes activity in alloxan induced diabetic mice (Mus musculus) Data represented as mean of six values and their standard errors.

\begin{tabular}{|c|c|c|c|c|c|c|}
\hline Tissues & Groups & ALT (KU/mg protein) & AST (KU/mg protein) & ALP (U/mg protein) & ACP (U/mg protein) & LDH (U/mg protein) \\
\hline \multirow{3}{*}{ Liver } & PC & $12.4 \pm 0.2$ & $110.2 \pm 0.6$ & $14.9 \pm 0.49$ & $9 \pm 0.2$ & $85.9 \pm 0.67$ \\
\hline & PD & $22.4 \pm 0.4$ * & $181.7 \pm 0.6^{*}$ & $24.2 \pm 0.54^{*}$ & $16 \pm 0.49^{*}$ & $219.5 \pm 0.7^{*}$ \\
\hline & $C D$ & $18.0 \pm 0.65^{*} \dagger$ & $162.7 \pm 0.72^{*} \dagger$ & $20.2 \pm 0.42^{*} \dagger$ & $14.6 \pm 0.50^{*}$ & $158.3 \pm 0.77^{*} \dagger$ \\
\hline \multirow{3}{*}{ Kidney } & PC & $9.57 \pm 0.37$ & $77.4 \pm 0.99$ & $11.87 \pm 0.26$ & $8.82 \pm 0.33$ & $99.1 \pm 1.08$ \\
\hline & PD & $16.8 \pm 0.40^{*}$ & $157.3 \pm 1.27^{*}$ & $26.3 \pm 0.55^{*}$ & $14.9 \pm 0.44^{*}$ & $175.1 \pm 1.6^{*}$ \\
\hline & $C D$ & $14.6 \pm 0.25^{\star} \dagger$ & $145.0 \pm 1.45^{*} \dagger$ & $21.7 \pm 0.55^{*} \dagger$ & $13.2 \pm 0.20^{*} \dagger$ & $146.5 \pm 1.4^{*} \dagger$ \\
\hline \multirow{3}{*}{ Heart } & PC & $7.9 \pm 0.31$ & $98.2 \pm 1.5$ & $12.6 \pm 0.36$ & $8.7 \pm 0.22$ & $102.1 \pm 1.1$ \\
\hline & PD & $15.1 \pm 0.34^{*}$ & $160 \pm 1.1^{*}$ & $18.8 \pm 038^{*}$ & $13.9 \pm 0.23^{*}$ & $187.4 \pm 1.08^{*}$ \\
\hline & $C D$ & $14.6 \pm 0.32^{*}$ & $148.9 \pm 1.2^{*} \dagger$ & $16.2 \pm 0.39^{*} \dagger$ & $12.9 \pm 0.22^{*} \dagger$ & $168.7 \pm 1.66^{*} \dagger$ \\
\hline \multirow{3}{*}{ Pancreas } & PC & $8.52 \pm 0.45$ & $102.1 \pm 1.29$ & $10.2 \pm 0.54$ & $7.9 \pm 0.28$ & $96.8 \pm 1.5$ \\
\hline & PD & $15.5 \pm 0.26^{*}$ & $145.8 \pm 1.61^{*}$ & $16.5 \pm 0.57^{*}$ & $12.9 \pm 0.22^{*}$ & $167.4 \pm 1.7^{*}$ \\
\hline & $C D$ & $13.0 \pm 0.40^{*} \dagger$ & $137.0 \pm 1.72^{*} \dagger$ & $13.8 \pm 0.50^{*} \dagger$ & $12.1 \pm 0.30^{*}$ & $141.8 \pm 1.02^{*} \dagger$ \\
\hline \multirow{3}{*}{ Serum } & PC & $12.84 \pm 0.88$ & $108.45 \pm 1.3$ & $15.8 \pm 0.67$ & $9.23 \pm 0.25$ & $136.1 \pm 1.34$ \\
\hline & PD & $27.1 \pm 0.98^{*}$ & $236.7 \pm 1.17^{*}$ & $26.36 \pm 0.68^{*}$ & $17.03 \pm 0.49^{*}$ & $231.1 \pm 1.26^{*}$ \\
\hline & $C D$ & $17.5 \pm 0.96^{*} \dagger$ & $117.6 \pm 1.47^{*} \dagger$ & $21.3 \pm 0.67^{*} \dagger$ & $15.0 \pm 0.57^{*} \dagger$ & $166.7 \pm 1.21^{*} \dagger$ \\
\hline
\end{tabular}

The significant difference between groups for each tissue based on student t test represented by * compared to PC, $†$ compared to PD.PC: Standard control, PD: Diabetic control, CD: Clarias oil group

Table 5: Effect of dietary supplementation of fish oils for 30 days on activity of enzymes in alloxan induced diabetic mice (Mus musculus). Data represented as mean of six values and their standard errors.

and plays important role in the biological systems for maintaining integrity of cell membrane, growth and development [22]. Present study focuses on the beneficial effect of fish oil extracted from fresh water fish Clarias batrachus on improvement of antioxidant status in diabetes induced mice. Due to alloxan injection which is capable of inducing type 1 diabetes by destruction of insulin producing beta cell of pancreatic islet, diabetic mice showed increase level of free sugar which is might be due to low insulin [23], and increased concentration of glycosylated haemoglobin which might be due to poor control of glucose metabolism [24]. Multiple enzymatic and non-enzymatic antioxidant defence systems are present in cells to protect the membranes and other cell organelles from the damaging effects of free radical reactions [25].

In the present study antioxidant and lipid peroxidation status alterations were observed in diabetic mice. The decrease in concentration of Vitamin C, Vitamin E, GSH and increase in concentration of TBARS is observed in diabetic mice when compared with control which is in accordance with previous reports indicating depletion in Vitamin C, Vitamin E, GSH content is due to higher level of free radicals generation $[22,26,27]$. The decrease in activity of enzymes SOD and catalase and increase in activity of GGT was observed in diabetic mice might be due to insulin insufficiency in Type 1 diabetes which results in increased hydrogen peroxide production due to increase in oxidation [28]. Because of the induction of hydrogen peroxide and due to the excessive enzyme consumption, reduction in tissue SOD and Catalase activity and increase in GGT activity is observed [29,30]. In alloxandiabetic mice the activities of AST, ALT, ALP, ACP and LDH were significantly increased compared to non-diabetic control. The increase in the activities of AST, ALT, ALP, ACP and LDH is directly related to changes in metabolism where in these enzymes are involved [31], generally due to diabetes induced hepatic impairment [32], and may be mainly due to the leakage of these enzymes from the necrotic liver into the blood stream, indicating hepatotoxic effects of alloxan, visàvis diabetes. The increased levels of these enzymes generally indicate increased gluconeogenesis and ketogenesis [31]. 
The supplementation of fish oil to the diabetic mice helps to improve the insulin concentration and decrease the elevated level of free sugar and glycosylated haemoglobin concentration as shown by our result which indicates fish oil may help to increase insulin action and may regulate glucose metabolism $[33,34]$. Fish oil supplementation to diabetic mice also helped to improve the antioxidant status. The fish oil supplementation aided to increase in the concentration of Vitamin $\mathrm{C}$, in the activity of SOD and catalase with decrease in concentration of TBARS. This indicates that the fish oil with PUFA is having beneficial effect on attenuation of oxidative stress, which is in relevance to previous reports which shows that fish oil PUFA specially EPA and DHA present in edible oils are having antioxidant potential [35-37]. But there is no significant changes in concentration of Vitamin $\mathrm{E}$ and GSH and in activity of GGT are observed in tissues of diabetic mice supplemented with fish oil. Fish oil supplementation to diabetic mice also provoked significant decrease in ALT, AST, ALP, ACP and LDH enzymes activity, which indicates effect of fish oil on activity of functional enzymes, particularly with reference to gluconeogenesis and ketogenesis [35,36]. In conclusion the study indicates that in diabetes due to hyperglycaemic condition and enhanced glucose metabolism through polyol pathway causes direct increase in ROS generation. The long term supplementation of fish oil extract from fresh water fish Clarias batrachus which is a good source of PUFA is having protective effect on tissue damage caused by prolonged diabetes. Although there are no changes in antioxidant parameters like Vitamin E and GSH is observed, the prolonged supplementation of Clarias oil might play a potential role in controlling oxidative stress and to improve antioxidant status.

\section{Disclosure Statement}

Authors have no conflict of interest to disclose.

\section{Acknowledgement}

Financial support from the University Grant Commission- Special Assistance Programme India (Sanction letter no. F.3-3/2011 (SAPII) is acknowledged.

\section{References}

1. http://www.who.int/mediacentre/factsheets/fs312/en/

2. Baynes JW (1991) Role of oxidative stress in development of complications in diabetes. Diabetes 40: 405-412.

3. Matough FA, Budin SB, Hamid ZA, Alwahaibi N, Mohamed J (2012) The role of oxidative stress and antioxidants in diabetic complications. Sultan Qaboos Univ Med J 12: 5-18.

4. Donath MY, Størling J, Maedler K, Mandrup-Poulsen T (2003) Inflammatory mediators and islet beta-cell failure: a link between type 1 and type 2 diabetes. J Mol Med (Berl) 81: 455-470.

5. Simopoulos AP (2002) Omega-3 fatty acids and cardiovascular disease: The epidemiological evidence. Environ Health Prev Med 6: 203-209.

6. Giacco F, Brownlee M (2010) Oxidative stress and diabetic complications. Circ Res 107: 1058-1070.

7. Miles EA, Calder PC (1998) Modulation of immune function by dietary fatty acids. Proc Nutr Soc 57: 277-292.

8. Perkins ND (2007) Integrating cell-signalling pathways with NF-kappaB and IKK function. Nat Rev Mol Cell Biol 8: 49-62.

9. Vanden Berghe W, Vermeulen L, Delerive P, De Bosscher K, Staels B, et al (2003) A paradigm for gene regulation: inflammation, NF-kappaB and PPAR. Adv Exp Med Biol 544: 181-196.

10. Calder PC (2010) Omega-3 fatty acids and inflammatory processes. Nutrients 2: $355-374$.

11. Tikhonenko M, Lydic TA, Wang Y, Chen W, Opreanu M, et al. (2010) Remodeling of retinal Fatty acids in an animal model of diabetes: a decrease in long-chain polyunsaturated fatty acids is associated with a decrease in fatty acid elongases Elovl2 and Elovl4. Diabetes 59: 219-227.

12. Siriwardhana N, Kalupahana NS, Moustaid-Moussa N (2012) Health benefits of n-3 polyunsaturated fatty acids: eicosapentaenoic acid and docosahexaenoic acid. Adv Food Nutr Res 65: 211-222.

13. Chougule A D, Panaskar S N, Gurao P M, Arvindekar A U (2007) Optimization of alloxan dose is essential to induce stable diabete for prolonged period. Asian J biochem 6: 402-408.

14. Uslu BA, Ilhan F, Gulyuzf F, Karaca M, Oner AC (2009) Assesment of histopathological changes occurring in the testis of the mice suffering from experimental diabetes induced using alloxan. J Anim Vet Adv 8: 1929-1935.

15. Chawla R (1999) Practile clinical biochemistry, methods and interpretation Jaypee Brothers Medical Publishers (p) Ltd India.

16. Nelson N (1994) A photometric adaptation of the Somogyi method for the determination of glucose. J Biol Chem 153: 375-80.

17. Chandalia HB, Sadikot S, Bhargav DK, Krishnaswamy PR (1980) Estimation of glycosylated hemoglobins by a simple chemical method and its use in monitoring control of diabetes mellitus. J Assoc Physicians India 28: 285-286.

18. Godkar PB, Godkar DP (2003) Text book of medical laboratory technology (2 edtn) Bhalani publishing house India.

19. Pujari PD (2010) Thesis: effect of dietary lipid on D-galactosamine induced hepatitis in swiss albino mice, Mus musculus. Goa University. Goa. India

20. Rohilla A, Ali S (2012) Alloxan induced diabetes; Mechanism and effect IJRPBS 3 (2): 819-823

21. Giacco F, Brownlee M (2010) Oxidative stress and diabetic complications. Circ Res 107: 1058-1070.

22. Zamaria N (2004) Alteration of polyunsaturated fatty acid status and metabolism in health and disease. Reprod Nutr Dev 44: 273-282.

23. Sharma N, Garg V (2009) Antidiabetic and antioxidant potential of ethanolic extract of Butea monosperma leaves in alloxan-induced diabetic mice. Indian J Biochem Biophys 46: 99-105.

24. Koenig RJ, Peterson CM, Jones RL, Saudek C, Lehrman M, et al. (1976) Correlation of glucose regulation and hemoglobin Alc in diabetes mellitus. $\mathrm{N}$ Engl J Med 295: 417-420.

25. Evans WJ (2000) Vitamin E, vitamin C, and exercise. Am J Clin Nutr 72 647S-52S.

26. Varma V, Varma M, Sarkar PD, Varma A, Vyas S, Kulkarni R (2011) Correlation of vitamin $\mathrm{C}$ with $\mathrm{HbA} 1 \mathrm{c}$ and oxidative stress in diabetes mellitus with or without nephropathy. Natl J Med Res 4: 151-155.

27. Gre§ A (2013) Effects of vitamin E, C and D supplementation on inflammation and oxidative stress in streptozotocin-induced diabetic mice. Int J Vitam Nutr Res 83: 168-175.

28. Wohaieb SA, Godin DV (1987) Alterations in free radical tissue-defense mechanisms in streptozocin-induced diabetes in rat. Effects of insulin treatment. Diabetes 36: 1014-1018.

29. Celik S, Akkaya H (2009) Total antioxidant capacity, catalase and superoxide dismutase on rats before and after diabetes. J Anim Vet Adv 8: 1503-1508.

30. Qujeq D, Rezvani T (2007) Catalase (antioxidant enzyme) activity in streptozotocin-induced diabetic rats. Int. J. Diabetes \& Metabolism 15: 22-24.

31. Udayakumar R, Kasthurirengan S, Mariashibu TS, Rajesh M, Anbazhagan VR, et al. (2009) Hypoglycaemic and hypolipidaemic effects of Withania somnifera root and leaf extracts on alloxan-induced diabetic rats. Int J Mol Sci 10: 2367 2382

32. Concepción Navarro M, Pilar Montilla M, Martín A, Jiménez J, Pilar Utrilla M (1993) Free radical scavenger and antihepatotoxic activity of Rosmarinus tomentosus. Planta Med 59: 312-314.

33. Lam T, Carpentier A, Lewis G, Werve G, Fantus IG, Giacca A (2003) Mechanisms of the free fatty acid-induced increase in hepatic glucose production. Am J Physiol Endocrinol Metab 284: E863-873.

34. Gordon es (1964) The Glucose-Fatty Acid Cycle in the Pathogenesis of Diabetes Mellitus. Trans Am Clin Climatol Assoc 76: 124-134.

35. Ikemoto S, Takahashi M, Tsunoda N, Maruyama K, Itakura H, et al. (1996) 
Citation: Kamat SG, Roy R (2015) Evaluation of Antioxidant Potential of Clarias Batrachus Oil in Alloxan Induced Diabetic Mice (Mus Musculus). J Diabetes Metab 6: 552. doi:10.4172/2155-6156.1000552

Page 6 of 6

High-fat diet-induced hyperglycemia and obesity in mice: differential effects of dietary oils. Metabolism 45: 1539-1546.

36. Soltan S, Soltan MS (2012) The effects of varieties sources of omega-3 fatty acids on diabetes in rats. FNS 3: 1404-1413.
37. Medeiros J, Mothe G, Aguila B, Mandarim-de-Lacerda CA (2005) Longterm intake of edible oils benefits blood pressure and myocardial structure in spontaneously hypertensive rat (SHR) and streptozotocin diabetic SHR. Prostaglandins \& other Lipid Mediat 78: 231-248. 